\title{
Study on Subdivision Adjustment of Water Injection Wells in Multi-Layer Sandstone Oilfield
}

\author{
Li Gang \\ Exploration and Development Research Institute of Daqing Oilfield Co Ltd. Daqing 163712,China
}

Keywords: Interlayer interference; Series parallel experiment; Utilization status; Subdivision limit

\begin{abstract}
Multilayer heterogeneous sandstone oilfield in high water cut stage, the longitudinal upper sand body heterogeneity, each layer there is a big difference to use, the interlayer interference law is not clear. The research on subdivision water injection for different types of reservoir boundaries. In different high and low permeability core combination of series and parallel experiments, clarified the EOR effect to improve the core combination of different subdivision water injection. Application of grey correlation method, the main factors affecting the breakdown of water to control. Through the pilot test statistics X, Y reservoir, define reasonable subdivision water injection adjustment limit, guide the injection wells scheme can better segment measuring and adjusting control work, high water horizon invalid circulation, strengthen the use of low water flooding zones, alleviate the contradiction between layers.
\end{abstract}

\section{Introduction}

Experiment scheme. In XY oilfield of the reservoir permeability distribution based on the actual design, the combination of different permeability, physical simulation was carried out in the case of continuous water injection, monitoring the core flow changes, analysis of the water absorbing capacity of the core, in order to further study in different regions and different types of reservoir in general water injection and stratified water conditions to determine the use of differences. Different types of storage layer and provide the basis for the block layer subdivision water injection line. The design of different combinations of 6 cores, each combination from heterogeneous artificial cores $(2.5 \mathrm{~cm}$ diameter) $* 10 \mathrm{~cm}$ (length) 2 groups, with $0.5 \mathrm{MPa}$ displacement pressure simulation of commingled water injection in 1 groups, in order to reduce the pressure for the simulation of subdivision water injection in 1 groups of high permeability cores in water flooding at $40 \%$ (Table 1). The difference of recovery ratio between different injection methods is compared, and the feasibility of enhancing waterflood recovery by subdividing water injection is verified. 
Table 1 Experimental scheme of series parallel combination of different permeability cores

\begin{tabular}{|c|c|c|c|c|}
\hline $\begin{array}{c}\text { Different } \\
\text { permeability } \\
\text { combination }(\mathrm{mD})\end{array}$ & $\begin{array}{c}\text { Differential } \\
\text { Multiple }\end{array}$ & $\begin{array}{c}\text { Displacement } \\
\text { Number } \\
\text { (time) }\end{array}$ & $\begin{array}{c}\text { First group plan } \\
\text { (simulated flooding) }\end{array}$ & $\begin{array}{l}\text { Second sets of programs } \\
\text { (simulated subdivision flooding) }\end{array}$ \\
\hline 5 and 10 & 2 & 2 & \multirow{6}{*}{$\begin{array}{l}\text { The constant } 0.5 \mathrm{MPa} \text { displacement pressure } \\
\text { difference, when two cores are displaced } \\
\text { together to } 98 \% \text { water, calculates the } \\
\text { recovery ratio, and compares the recovery } \\
\text { ratio of different core combinations }\end{array}$} & \multirow{6}{*}{$\begin{array}{l}\text { When simulating waterflooding } \\
\text { development to } 40 \% \text { water cut, the } \\
\text { displacement ratio of high permeability } \\
\text { core is decreased, and the recovery ratio } \\
\text { of two cores to } 98 \% \text { different water } \\
\text { content is calculated respectively }\end{array}$} \\
\hline 5 and 15 & 3 & 2 & & \\
\hline 5 and 25 & 5 & 2 & & \\
\hline 5 and 50 & 10 & 2 & & \\
\hline 5 and 100 & 20 & 2 & & \\
\hline 5 and 200 & 40 & 2 & & \\
\hline
\end{tabular}

Experimental results and understanding. Results: the combination of multiple cores of different permeability differential is greater, more serious heterogeneity, general series simulation experiment of water flooding, the oil recovery is low overall combined core (Figure 2); subdivision water flooding parallel simulation experiment, different core combination of overall recovery has been improved, which combined core difference the greater the multiple segments after water injection EOR is larger (Figure 3).

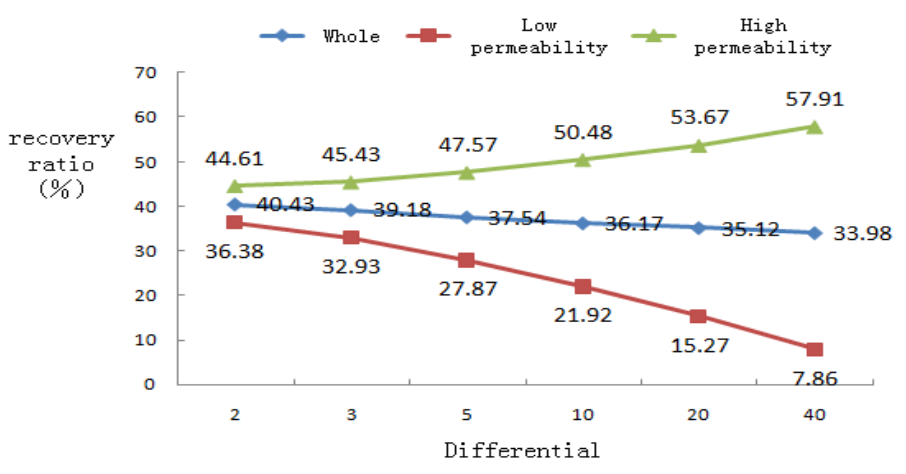

Fig. 1 simulation experiment of different core combination

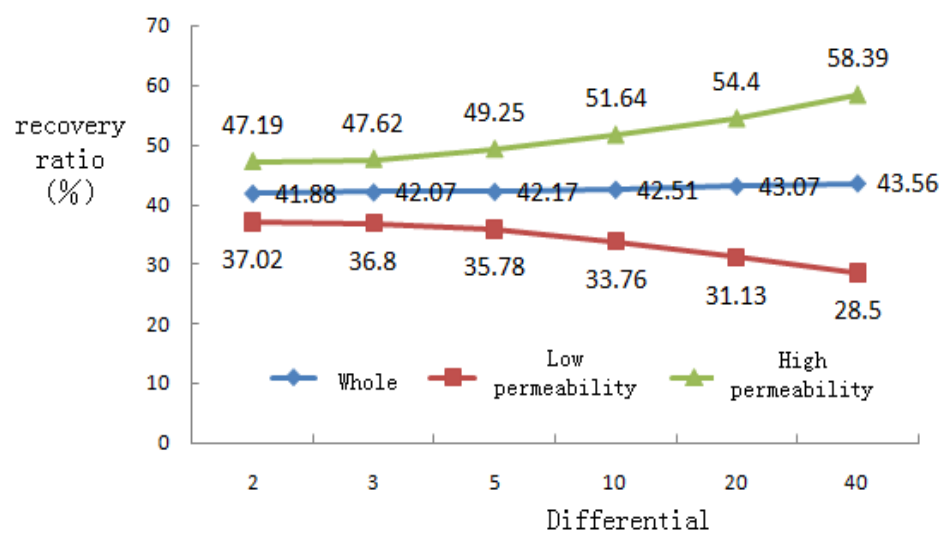

Fig. 2 subdivision water injection experiment with different core combination

\section{Analysis of main influencing factors of production condition}

Consider a variety of factors affecting subdivision injection layers water injection effect, determine the system behavior reflect the reference sequence of $\mathrm{X} 0(\mathrm{k})$ and the influence of the 
behavior of the system of comparative sequence Xi (k) (i=1,2,3, V, m).

Using the extreme value method, the raw data of influencing factors of water injection effect are treated with dimensionless method. By using the method of grey relational analysis, the influence factors of the effective thickness, percentage of water absorption, and the factors affecting the daily gain of 61 wells in the well are analyzed and calculated in a vertical way. The grey relational analysis is used to calculate the influence factors of the daily gain of 50 wells (Table 2).

Grey correlation analysis results showed that the layer number and the development of reservoir, the ratio of the number of layers within card effective thickness, effective thickness, inner layer connectivity layer section connecting well number and layers within the permeability variation coefficient is the main factor affecting the effect of injection。

Table 2 Correlation table of influencing factors of effective thickness

\begin{tabular}{|c|c|c|c|c|c|c|}
\hline \multicolumn{2}{|c|}{ Reference Series } & \multirow{2}{*}{$\begin{array}{l}\begin{array}{l}\text { Effective thickness percentage of water } \\
\text { absorption }\end{array} \\
\begin{array}{l}\text { Maximum permeability differential } \\
\text { multiple }\end{array} \\
\end{array}$} & \multirow{2}{*}{ (\%) } & \multirow{2}{*}{$\mathrm{x}_{0}$} & \multirow{2}{*}{$\begin{array}{c}\begin{array}{c}\text { Relational } \\
\text { grade }\end{array} \\
0.7064\end{array}$} & \multirow{2}{*}{ sort } \\
\hline \multirow{12}{*}{$\begin{array}{l}\text { Influence } \\
\text { series }\end{array}$} & \multirow{5}{*}{$\begin{array}{l}\text { Geological } \\
\text { parameter }\end{array}$} & & & & & \\
\hline & & $\begin{array}{l}\text { Ratio of number of layers to reservoir } \\
\text { number }\end{array}$ & - & $\mathrm{x}_{2}$ & 0.7668 & 1 \\
\hline & & $\begin{array}{l}\text { The effective thickness of layers within } \\
\text { the card }\end{array}$ & (m) & $\mathrm{x}_{3}$ & 0.7566 & 2 \\
\hline & & Section within card number & (layer) & $\mathrm{x}_{4}$ & 0.7126 & 6 \\
\hline & & $\begin{array}{l}\text { Coefficient of permeability variation in } \\
\text { formation }\end{array}$ & - & $\mathrm{x}_{5}$ & 0.7333 & 5 \\
\hline & \multirow{4}{*}{$\begin{array}{l}\text { Development } \\
\text { parameter }\end{array}$} & $\begin{array}{l}\text { Difference between injection pressure } \\
\text { and fracture pressure }\end{array}$ & (MPa) & $\mathrm{x}_{6}$ & 0.6696 & 11 \\
\hline & & $\begin{array}{l}\text { Maximum water cut difference in well } \\
\text { area }\end{array}$ & (\%) & $\mathrm{x}_{7}$ & 0.6698 & 10 \\
\hline & & Number of connected oil wells in section & - & $\mathrm{x}_{8}$ & 0.7351 & 4 \\
\hline & & Effective thickness in section & (m) & $\mathrm{x}_{9}$ & 0.7361 & 3 \\
\hline & \multirow{3}{*}{$\begin{array}{l}\text { Management } \\
\text { parameter }\end{array}$} & Qualified rate of water injection & (\%) & $\mathrm{X}_{10}$ & 0.6124 & 12 \\
\hline & & $\begin{array}{l}\text { Average interval between two washing } \\
\text { wells }\end{array}$ & (day) & $\mathrm{X}_{11}$ & 0.704 & 8 \\
\hline & & $\begin{array}{l}\text { Mean interval between two } \\
\text { measurements }\end{array}$ & (day) & $\mathrm{X}_{12}$ & 0.6999 & 9 \\
\hline
\end{tabular}

\section{Study on subdivision water injection limit of different types of oil reservoirs}

The effective thickness of water percentage is more than $70 \%$ as the standard, to determine the $\mathrm{X}$ and $\mathrm{Y}$ layer of each of the 5 parameters by field practice statistics. It is suggested to subdivide the water flooding development as much as possible to ensure the balanced utilization of the small layers. 
Table 3 Table of subdivision limits for different types of oil reservoirs in XY Oilfield

\begin{tabular}{c|c|c|c|c|c}
\hline \multirow{2}{*}{ oil layer } & \multicolumn{2}{|c|}{ portrait } & \multicolumn{2}{c}{ plane } \\
\cline { 2 - 5 } & $\begin{array}{c}\text { Ratio of the number of } \\
\text { injected layers to the } \\
\text { number of oil } \\
\text { reservoirs }\end{array}$ & $\begin{array}{c}\text { A card within the } \\
\text { effective thickness } \\
\text { (m) }\end{array}$ & $\begin{array}{c}\text { Coefficient of } \\
\text { permeability variation } \\
\text { in section }\end{array}$ & $\begin{array}{c}\text { Number of connected } \\
\text { oil wells in section }\end{array}$ & $\begin{array}{c}\text { Effective thickness in } \\
\text { section } \\
\text { (m) }\end{array}$ \\
\hline $\mathrm{X}$ & $\geq 0.5$ & $<4$ & $<0.5$ & $\geq 3$ & $\geq 3$ \\
\hline $\mathrm{Y}$ & $\geq 0.4$ & $<5$ & $<0.5$ & $\geq 2$ & $\geq 5$ \\
\hline
\end{tabular}

\section{Field application practice}

Application of new subdivision boundaries to re evaluate various types of reservoir subdivision standards, and $\mathrm{X}$ reservoir and $\mathrm{Y}$ reservoir main blocks are basically up to standard (Table 4). From the analysis of interlayer water in small layer thickness of $2.0 \mathrm{~m}$, the effective thickness of water absorption proportion has remained at a high level over 75\%; thin effective thickness less than $2.0 \mathrm{~m}$ layer use conditions significantly improved, the effective thickness of water absorption ratio reached $69.2 \%$.

Table 4 Different types of oil reservoir subdivision on the table

\begin{tabular}{|c|c|c|c|c|c|}
\hline \multirow[b]{2}{*}{$\begin{array}{l}\text { oil } \\
\text { layer }\end{array}$} & \multicolumn{3}{|c|}{ The longitudinal } & \multicolumn{2}{|c|}{ The plane } \\
\hline & $\begin{array}{c}\text { Ratio of the } \\
\text { number of injected } \\
\text { layers to the } \\
\text { number of oil } \\
\text { reservoirs }\end{array}$ & $\begin{array}{l}\text { A card within the } \\
\text { effective thickness } \\
\text { (m) }\end{array}$ & $\begin{array}{c}\text { Coefficient of } \\
\text { permeability } \\
\text { variation in section }\end{array}$ & $\begin{array}{c}\text { Number of } \\
\text { connected oil wells } \\
\text { in section }\end{array}$ & $\begin{array}{l}\text { Effective thickness } \\
\text { in section } \\
\text { (m) }\end{array}$ \\
\hline \multirow{2}{*}{$\mathrm{X}$} & 0.49 & 4.2 & 0.5 & 2.8 & 3.6 \\
\hline & near & near & Standard & near & Standard \\
\hline \multirow{2}{*}{$\mathrm{Y}$} & 0.38 & 4.6 & 0.51 & 3.2 & 5.7 \\
\hline & near & Standard & near & Standard & Standard \\
\hline
\end{tabular}

\section{Conclusions}

1.The bigger the difference ratio of different permeability core combinations, the more serious the heterogeneity is, the lower the general water injection recovery ratio. The recovery efficiency of core flooding with different permeability can be improved by subdividing water injection;

2.Application of grey correlation analysis of mathematical methods, established the reservoir use mathematical model of factors of influence, clear water injection interval number and the ratio of the number of reservoir development, inner layer card effective thickness, permeability variation coefficient, interval interval number and interval connecting well connected 5 parameters for the effective thickness the main factors affecting reservoir production.

\section{Reference}

[1] Xu Jianjun, Xu Yan-chao, Yan, Li-me,et.al. Research on the method of optimal PMU placement. International Journal of Online Engineering,v9, S7, p24-29, 2013

[2] Xu Jian-Jun, Y. Y. Zi., Numerical Modeling for Enhancement of Oil Recovery via Direct Current. International Journal of Applied Mathematics and Statistics , 2013， 43(13): 318-326 
[3] Longchao, Zhu Jianjun, Xu; Limei, Yan. Research on congestion elimination method of circuit overload and transmission congestion in the internet of things. Multimedia Tools and Applications, p 1-20, June 27, 2016

[4] Yan Limei, Zhu Yusong, Xu Jianjun,et.al. Transmission Lines Modeling Method Based on Fractional Order Calculus Theory. TRANSACTIONS OF CHINA ELECTROTECHNICAL SOCIETY, 2014 ,Vol.29,No. 9:260-268 (In Chinese)

[5] YAN Li-mei, CUI Jia, XU Jian-jun,et.al. Power system state estimation of quadrature Kalman filter based on PMU/SCADA measurements. Electric Machines and Control. 2014, Vol.18 No.6,: 78-84. (In Chinese)

[6] YAN Limei,XIE Yibing, XU Jianjun, et.al. Improved Forward and Backward Substitution in Calculation of Power Distribution Network with Distributed Generation. JOURNAL OF XI'AN JIAOTONG UNIVERSITY,2013, Vol.47, No.6, p117-123. (In Chinese)

[7] Xu J.J., Gai D., Yan L.M. A NEW FAULT IDENTIFICATION AND DIAGNOSIS ON PUMP VALVES OF MEDICAL RECIPROCATING PUMPS. Basic \& Clinical Pharmacology \& Toxicology, 2016,118 (Suppl. 1), 38-38

[8] Xu Jianjun, Wang Bao'e, Yan Limei, Li Zhanping. The Strategy of the Smart Home Energy Optimization Control of the Hybrid Energy Coordinated Control. Transactions of China Electrotechnical Society, 2017, 32(12) 214-223. 